\title{
Analysis of proteomic profiling of mouse embryonic stem cells derived from fertilized, parthenogenetic and androgenetic blastocysts
}

\author{
Xiang-Shun Cui ${ }^{1}$, Xing-Hui Shen ${ }^{2}$, Chang-Kwon Lee ${ }^{3}$, Yong-Kook Kang ${ }^{4}$, \\ Teruhiko Wakayama ${ }^{5}$, Nam-Hyung Kim ${ }^{1,{ }^{*}}$ \\ ${ }^{1}$ Department of Animal Science, Chungbuk National University, Cheongju, Chungbuk, Korea
${ }^{2}$ Department of Histology and Embryology, Harbin Medical University, Harbin, Heilongjiang Province, China
${ }^{3}$ Department of Physiology, Konkuk University, Chungju City, Chungbuk, Korea
${ }^{4}$ Laboratory of Development and Differentiation, Korea Research Institute of Bioscience and Biotechnology, Daejeon, South Korea
${ }^{5}$ Center for Developmental Biology, RIKEN Kobe, Kobe, Japan; nhkim@chungbuk.ac.kr
}

Received January 23 2011; revised March 13 2011; accepted March 202011.

\begin{abstract}
Embryonic stem cells (ESCs) are derived from the inner cell mass (ICM) of preimplantation embryos. ESCs exhibit true pluripotency, i.e., the ability to differentiate into cells of all three germ layers in the developing embryo. We used 2-DE MALDI-TOF/TOF to identify differentially expressed proteins among three types of mouse embryonic stem cells (ESCs) derived from fertilized, parthenogenetic, and androgenetic (fESC, pESC and aESC, respectively) blastocysts. We detected more than 800 proteins on silverstained gels of whole protein extracts from each type of ESC. Of these, 52 differentially expressed proteins were identified by the MALDI-TOF/TOF analyzer, including 32 (fESCs vs. pESCs), 28 (fESCs vs. aESCs) and 17 (pESCs vs. aESCs) prominent proteins with significantly higher or lower expression relative to the comparison cells. Among the 32 proteins from fESCs, 12 were significantly increased in expression and 20 were reduced in expression in fESCs compared with pESCs. Similarly, 10 of 28 and 8 of 17 proteins were more highly expressed in fESCs and $\mathrm{pESC}$ s compared with aESCs, respectively. In contrast, 18 of 28 and 9 of 17 proteins were reduced in expression in fESCs and pESCs compared with aESCs, respectively. Of the eight protein candidates in fESCs, four were increased and four were decreased in expression relative to both pESCs and aESCs in the 2-DE analysis. Differential expression of these proteins were confirmed by mRNA expression analysis using real time RT-PCR. For three pro-
\end{abstract}

teins, ANXA5, CLIC1 and SRM, Western blot analysis corroborated the expression patterns indicated by the 2-DE results. ANXA5 and CLIC1 were increased in expression and SRM was decreased in expression in fESCs compared with both pESCs and aESCs. The differentially expressed proteins identified in the present study warrant further investigation towards the goal of their potential application in ESC therapy.

Keywords: Protein Profiling; Embryonic Stem Cell; Parthenogenote; Androgenote; Fertilization

\section{INTRODUCTION}

The field of stem cell biology has attracted increasing attention in recent years due to the plasticity of stem cells and their broad potential for use in cell therapy. Despite this focus, relatively little is known about the mechanisms underlying the regulation and thereby the potential for the manipulation of stem cells for clinical applications. Embryonic stem cells (ESCs) are pluripotent cells derived from the inner cell mass (ICM) of blastocysts. ES cells can proliferate indefinitely in vitro and can differentiate into a wide variety of cell types both in vivo and in vitro $[1,2]$. Because of their exceptional properties, ESCs have enormous potential to be used for developmental biology studies, drug screening, tissue engineering and transplantation therapy.

Recently, stem cell research has begun to be applied in clinical settings. ESCs could be especially helpful therapeutically in that they could help to overcome immune rejection problems. In particular, parthenogenetic embryonic stem cells (pESCs) could advance the field of regenerative medicine by avoiding the immune rejection 
problems inherent in transplantation. pESCs are able to differentiate into cell types from all three germ layers and are immunologically matched with their oocyte donors [3]. The other uniparental cells, androgenetic ES Cells (aESCs), can be established from androgenotes, which cannot develop into viable fetuses. Like pESCs, aESCs can also be generated with a full complement of major histocompatibility complex antigens [4]. A previous report suggested that pESCs were indistinguishable from ESCs derived from fertilized embryos (fESCs) [5]. However, a detailed understanding of signalling pathways and molecular mechanisms involved in biparental and uniparental pluripotency will be essential before using them in ESC-based therapies.

Over the past few years, there has been a growing interest in applying proteomics to the study of proteins in ESCs [6,7]. Although previous studies have generated a wealth of data, the molecular mechanisms that determine the characteristics of ESCs remain largely unknown. In general, little is known about the functional aspects of ESC-specific proteins. Moreover, in contrast to fESCs, no detailed comparisons of the proteins expressed in pESCs and aESCs have been undertaken. In this study, we used two-dimensional gel electrophoresis (2-DE) and matrix-assisted laser desorption/ionization time-of-flight mass spectrometry (MALDI-TOF/TOF MS) to analyze protein patterns in mouse ESCs. This is the first report to display the global cellular protein profiles in mono- and bi-parentally derived ESCs, and in particular to identify the protein signatures for multipotency in fESCs, pESCs and aESCs.

\section{MATERIALS AND METHODS}

\subsection{Cell Culture, Differentiation in Vitro and Sample Preparation}

Mouse ES cell lines, derived from fertilized (fESC1 and 2, line 1 and 2, respectively), parthenogenetic (pESC1 and 2), and androgenetic (aESC1 and 2) blastocysts, were kindly provided by Dr. Wakayama (Center for Developmental Biology, RIKEN Kobe, Japan). Each type of blastocysts were generated by fertilization, parthenogenetically activated by strontium chloride $\left(\mathrm{SrCl}_{2}\right)$ following cytochalasin B (CB, Sigma) treatment $6 \mathrm{~h}$ and two sperm heads were injected into enucleated oocytes for generation of androgenote embryos. Embryos were cultured in M16 medium for 4 days. ESCs were established based on general methods using inner cell mass (ICM) of single blastocyst. The fESC1, pESC1 and aESC1 cell lines were used for two-dimensional gel electrophoresis (2-DE) analysis, and experiments were repeated three times using passages 6,7 and 8 , respectively. All ESCs were maintained on non-gelatin coated dishes in DMEM (high glucose; Invitrogen, Carlsbad, CA, USA) supplemented with $15 \%$ fetal calf serum, 0.1 $\mathrm{mM}$ b-mercaptoethanol, $1000 \mathrm{U} / \mathrm{mL}$ recombinant mouse LIF (ESGRO; Chemicon International, Temecula, CA, USA), 1\% glutamine (Sigma, St Louis, MO, USA), 0.5\% penicillin/ streptomycin (Sigma), and 1\% non-essential amino acids (Sigma). fESCs, pESCs and aESCs were differentiated by treatment with $1 \mathrm{mM}$ retinoic acid (RA, Sigma) for 6 days (fRA, pRA and aRA, respectively).

Protein samples were prepared essentially as described in Lee et al. [8] reports. The cultured cells were harvested with 2-DE lysis buffer containing $8 \mathrm{M}$ Urea, 2 $M$ thiourea, $100 \mathrm{mM}$ DTT, 4\% CHAPS and $1 \times$ complete protease inhibitor cocktail (Roche Applied Science, Germany). The lysates were incubated for $20 \mathrm{~min}$ and centrifuged at $12000 \times \mathrm{g}$ for $10 \mathrm{~min}$ at $10^{\circ} \mathrm{C}$. The supernatants were diluted with rehydration buffer containing $7 \mathrm{M}$ Urea, $2 \mathrm{M}$ thiourea, $100 \mathrm{mM}$ DTT, 2\% CHAPS $0.5 \%$ ampolyte (Bio-Rad) and $0.01 \%$ bromophenol blue, and then used as the sample to 2-DE analysis.

\subsection{2-DE, in-Gel Digestion and MAL- DI-TOF/TOF MS}

2-DE was performed as described in Lee et al. [8]. Images of silver-stained gels were digitized with a densitometer (VersaDoc Imaging System $1000^{\mathrm{TM}}$ ). The gels were normalized and statistically analyzed with PDQuest software (Version 7.1.1, Bio-Rad).

In-gel digestion and identification of the altered protein spots were performed as reported previously. [8] Briefly, the protein spots were digested with trypsin and desalted with ZipTip $\mathrm{C}_{18}$ (Millipore). The peptide samples were mixed with CHCA matrix solution and then analyzed by MALDI-TOF/TOF (AB4700, Applied Biosystems) in the reflector mode.

Spectra were processed and analyzed with the Global Protein Server Explorer 3.0 software (Applied Biosystems). The internal MASCOR (Matrix Science, UK) program was used for matching MS and MS/MS data against database information. The resulting data were surveyed against mouse databases downloaded from both NCBI and the Swiss Prot/TrEMBL homepage.

\subsection{Genomic DNA Polymerase Chain Reaction (PCR)}

Whole genomic DNA was extracted by phenol/chloroform method. PCR reaction was carried out in $25 \mu \mathrm{l}$ volumes, containing distilled water, $2.5 \mu \mathrm{l}$ of reaction buffer, $200 \mu \mathrm{M}$ of dNTPs, 2.0 units of Taq DNA polymerase (Promega, USA), $10 \mathrm{mM}$ of each primer for Zinc finger protein 1, Y linked (Zfy1), Zinc finger protein $\mathrm{X}$-linked $(Z f x)$ and Ras association domain family member 1 (Rassf1) genes (Table 1), and about $100 \mathrm{ng}$ of 
total DNA. Amplification was performed following conditions: an initial 2-min denaturation at $94^{\circ} \mathrm{C}$ was followed by 30 cycles of $30 \mathrm{~s}$ at $94^{\circ} \mathrm{C}, 45 \mathrm{~s}$ at $55^{\circ} \mathrm{C}-60^{\circ} \mathrm{C}$, and $60 \mathrm{~s}$ at $72^{\circ} \mathrm{C}$. The PCR products for 3 genes were separated on $2.0 \%$ agarose gels containing ethidium bromide.

\subsection{Reverse Transcriptase-Polymerase Chain Reaction (RT-PCR) and Real Time RT-PCR}

Messenger RNA was extracted with the Dynabeads
mRNA Direct Kit (Dynal Asa, Oslo, Norway), standard cDNA synthesis was achieved by reverse transcription of RNA using the oligo(dT) 12 - 18 primer and superscript reverse transcriptase (Invitrogen Co., Grand Island, NY).

For determination of pluripotency and differentiation, mRNA expression in the ESCs and differentiated cells were analyzed by RT-PCR using cDNA as the template, and following primers: POU domain, class 5, transcription factor 1 (Pou5f1, Oct4), Nanog homeobox (Nanog), Paired box gene 6 (Pax6), Nestin (Nes) and glyceraldehyde-3-phosphate dehydrogenase (Gapdh, Table 1).

Table 1. Primers used in PCR.

\begin{tabular}{|c|c|c|c|c|}
\hline Name & Acc. No. & Sequence & Length (bp) & $P C R$ \\
\hline Zfy1 & AK076618 & $\begin{array}{l}F: \text { gtaggaagaatcttctcatgctgg } \\
R: \text { ttttgagtgctgatgggtgacgg }\end{array}$ & 217 & Genomic DNA \\
\hline$Z f x$ & $A L 626786$ & $\begin{array}{l}F: \text { atggtacatgtctataatcttagcatt } \\
R: \text { ctaccagggattaaactggttaacat }\end{array}$ & 210 & Genomic DNA \\
\hline Rassf1 & NC_000075 & $\begin{array}{l}F: \text { tgaaacaccttccttcgaaatg } \\
R: \text { caccctttcaagcttcagagtt }\end{array}$ & 420 & Genomic DNA \\
\hline Oct4 & NM_013633 & $\begin{array}{l}F: \text { tgtggacctcaggttggact } \\
R: \text { cttctgcagggcttcatgt }\end{array}$ & 221 & $R T$ \\
\hline Nanog & NM_028016 & $\begin{array}{l}F: \text { aacgatatggtggctactctc } \\
R: \text { tcggttcatcatggtacagt }\end{array}$ & 264 & $R T$ \\
\hline Pax6 & NM_013627 & $\begin{array}{l}F: \text { ctgcagacccatgcagatgcaaa } \\
R: \text { aagtcgcatctgagcttcatccg }\end{array}$ & 519 & $R T$ \\
\hline Nes & NM_016701 & $\begin{array}{l}F: \text { aagctgaagctgcatttccttg } \\
R: \text { gtgctaagctgtttctactttt }\end{array}$ & 550 & $R T$ \\
\hline Gapdh & NM_008084 & $\begin{array}{l}F: \text { aaaccrgccaagtatgatga } \\
R: \text { gtggtccagggttcttact }\end{array}$ & 273 & $R T /$ Real time $R T$ \\
\hline Anxa5 & NM_009673 & $\begin{array}{l}F: \text { gaagccctcacgactctacg } \\
R: \text { tatccccaccacatcatct }\end{array}$ & 179 & Real time $R T$ \\
\hline Erp29 & NM_026129 & $\begin{array}{l}F: \text { cctgaagatcatggggaaga } \\
R: \text { ctcctccttctcagcctcct }\end{array}$ & 172 & Real time $R T$ \\
\hline Clic1 & NM_033444 & $\begin{array}{l}F: \text { ctctggctcaagggagtcac } \\
R: \text { atatgtccagtccogaggtg }\end{array}$ & 232 & Real time $R T$ \\
\hline Po protein & $X 15267$ & $\begin{array}{l}F: \text { tgccacactccatcatcaat } \\
R: \text { cgaagagaccgaatcccata }\end{array}$ & 240 & Real time $R T$ \\
\hline Srm & NM_009272 & $\begin{array}{l}F: \text { gtcctacgggaagtggtgaa } \\
R: \text { gtcctacgggaagtggtgaa }\end{array}$ & 199 & Real time $R T$ \\
\hline Strap & NM_011499 & $\begin{array}{l}F: \text { tcagtcctgatggggaactc } \\
R: \text { tctggaaatccgatcttgg }\end{array}$ & 154 & Real time $R T$ \\
\hline Sod1 & AH002084 & $\begin{array}{l}F: \text { ccagtgcaggacctcatttt } \\
R: \text { ttgtttctcatggaccacca }\end{array}$ & 197 & Real time $R T$ \\
\hline Esrra & NM_007953 & $\begin{array}{l}F: \text { ccaggcttctcctcactgtc } \\
R: \text { gcccctcttcatctaggac }\end{array}$ & 152 & Real time $R T$ \\
\hline$B c l-x L$ & L35049 & $\begin{array}{l}F: \text { ttcgggatggagtaaactgg } \\
\text { R:tggatccaaggctctaggtg }\end{array}$ & 157 & Real time RT \\
\hline Birc5 & NM_009689 & $\begin{array}{l}F: \text { gaatcctgcgtttgagtggt } \\
R: \text { aaaacactgggccaaatcag }\end{array}$ & 221 & Real time $R T$ \\
\hline Casp3 & $B C 038825$ & $\begin{array}{l}F: \text { gggcctgttgaactgaaaaa } \\
R: \text { ccgtcctttgaattctcca }\end{array}$ & 242 & Real time $R T$ \\
\hline Bax & NM_007527 & $\begin{array}{l}F: \text { tgcagaggatgattgctgac } \\
R: \text { gatcagctcgggcactttag }\end{array}$ & 183 & Real time $R T$ \\
\hline
\end{tabular}

$\mathrm{F}$, forward; $\mathrm{R}$, reverse. 
Gapdh amplification was used as a loading control for the sample. PCR conditions were as follows: $95^{\circ} \mathrm{C}$ for 30 $\mathrm{s}, 55^{\circ} \mathrm{C}-60^{\circ} \mathrm{C}$ for $30 \mathrm{~s}$ and $72^{\circ} \mathrm{C}$ for $1 \mathrm{~min}$. The PCR products for 5 genes were separated on $2.0 \%$ agarose gels containing ethidium bromide.

Cell lines from $\mathrm{fESC} 1 / 2, \mathrm{pESC} 1 / 2$, and $\mathrm{aESC} 1 / 2$ were used for real time RT-PCR. Real-time RT-PCR was performed using the 13 primer sets shown in Table 1 using the DNA Engine OPTICOJ 3 (MJ research, USA). Relative gene expression was quantified using the 2-ddCt method. Gapdh mRNA, a house keeping gene, was employed as a control.

\subsection{Western Blot Analysis}

Western blot analysis was performed as described previously [9]. Briefly, ESC lysates were separated by electrophoresis in a CriterionTM Precast Gel (Bio-Rad, Hercules, CA), followed by transfer to a PVDF membrane (iBlot TM Gel Transfer Stacks, Cat. No. IB4010-02; Invitrogen). After blocking, the membrane was incubated with primary anti-ANXA5 (GenWay Biotech, Inc., CA, USA), anti-CLIC1 (Aviva Systems Biology, CA, USA), anti-SRM (GeneTex, CA, USA), and anti-GAPDH (Cell Signaling Technology, Danvers, MA, USA). Then, the membrane was incubated with HRP-linked anti-rabbit IgG (Cell Signaling Technology). Finally, the antibody-binding bands on the membrane were visualized using Chemiluminescence Luminol Reagent (Invitrogen).

\subsection{Statistical Analysis}

The general linear model (GLM) procedure in the SAS program [10] was applied to analyze data from all experiments. Significant differences were determined using Tukey's multiple range test [11] and $\mathrm{P}<0.05$ was considered statistically significant.

\section{RESULTS}

\subsection{Sex Diagnosis and Characterization of ESC and Differentiated Cell Lines}

ESC lines which were established from Dr. Wakayama were well characterized for their pluripotency and differentiation potential including karyotypping [12,13] and chimera formation [14]. To determine accuracy of genotype diagnosis of ESCs, PCR amplification of Zfy1/Zfx were employed. Genes common to $\mathrm{X}$ and $\mathrm{Y}$ chromosomes (ZFY/ZFX, zinc finger protein) can amplify by a single primer pair. As shown in Figure 1 (a), both fESCs and aESCs contain both X and Y chromosomes, whereas pESCs only shows $\mathrm{X}$ chromosome, the same to the adult somatic female cells (fm) that were used as a positive control. Rassf1 was used as a genomic DNA positive control, expressed all samples except for negative control, no template group.

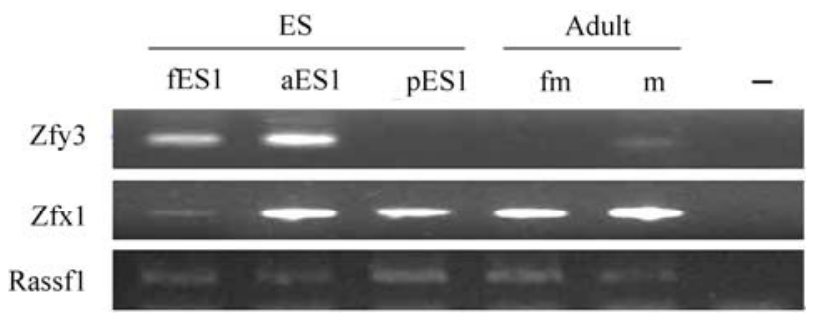

(a)

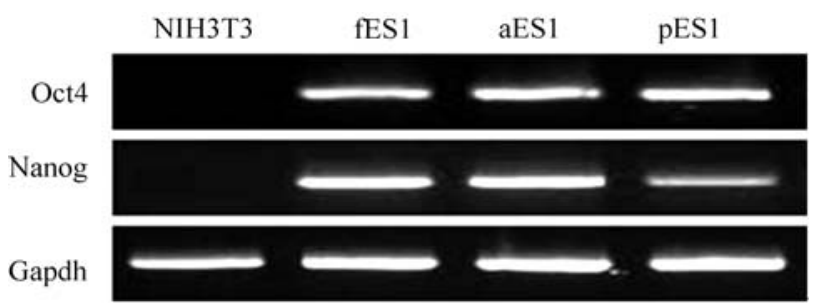

(b)

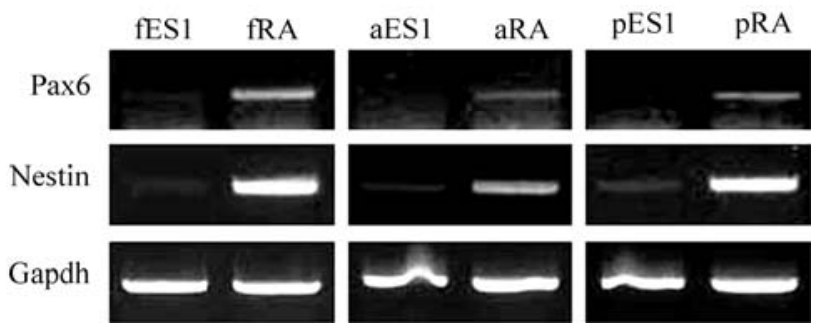

(c)

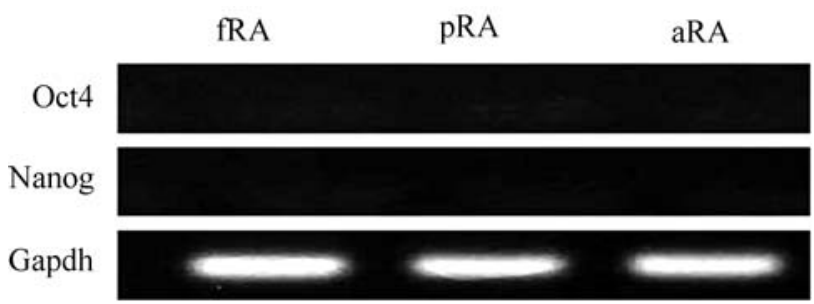

(d)

Figure 1. (a), Representative PCR sexing reactions. PCR products were generated from embryonic stem cells (ESCs) or adult somatic cells (ASCs). Characterization of pluripotency (b) neuroprogenitors (c) and differentiated state 6 days after retinoic acid treatment (d) by RT-PCR. fES: fertilized embryonic stem cells; aES: androgenetic embryonic stem cells; pES: parthenogenetic embryonic stem cells; fm: adult female cells; m: adult male cells; -: no template. fRA, aRA and pRA: fESC, aESC and pESC were differentiated by retinoic acid, respectively. Adult somatic cells (ASCs) from $\mathrm{fm}$ (female) and $\mathrm{m}$ (male) were used as positive control in (A); Rassf1 was used as genomic DNA positive control and no DNA template (-) was used as a negative control in (a); NIH3T3 cell was used as a negative control in (b); Gapdh was used as a positive control in (b), (c) and (d). 
Embryonic stem cells and ESC-derived neuroectodermal spheres (NESs) were shown to have characteristics typical of pluripotency and neuroprogenitors. RTPCR results showed that ESC marker genes Oct4 and Nanog were expressed in ESC lines but did not express in control (NIH3T3) cell line (Figure 1 (b)). An the other hand, neural stem cell marker genes such as Nes and Pax6 were expressed at markedly increased levels in the NESs compared with the ESCs (Figure 1 (c)). In contrast, Oct4 and Nanog were not expressed in fRA, pRA and aRA cells which were treated with retinoic acid for 6 days, and all of them were shown with differentiated state (Figure 1 (d)).

\subsection{Comparative Proteomics in fESCs, pESCs and aESCs}

To identify differentially expressed proteins between fESCs vs. pESCs, fESCs vs. aESCs, and pESCs vs. aESCs, proteins were separated using the 2-DE tech- nique, and experiments were repeated three times for each ESC type, using different passages. Separated proteins were visualized with silver staining and analyzed with PDQuest software. Figures 2(a), 3(a) and 4(a) show typical 2-DE gels of total ESC proteins for the three groups. In total, more than 800 proteins may be seen in each gel, with isoelectric $\mathrm{pH}$ values of $\mathrm{pH}$ 3-10 and molecular weights (MW) of 14 - $180 \mathrm{kDa}$. The MALDI-TOF/TOF analyzer identified 52 differentially expressed proteins among the three types of ESCs, with gels placed side-by-side for ease of comparison between groups (Figure 2(b), 3(b) and 4(b)). We identified 32 (fESCs vs. pESCs, Table 2), 28 (fESCs vs. aESCs, Table 3), and 17 (pESCs vs. aESCs, Table 4) prominent proteins in each comparison. Tables 2-4 list these proteins, highlight representative peptide sequences and sequence coverage, note the theoretical and experimental isoelectric point $(\mathrm{p} I)$ and MW values, and provide accession numbers from both the Swiss-Prot and NCBI databases.
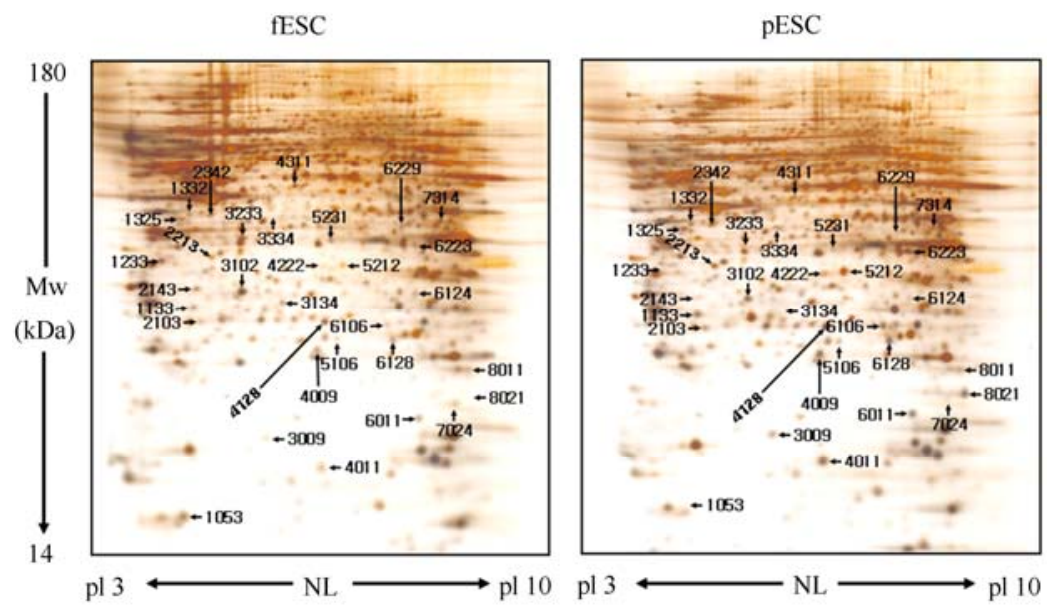

(a)

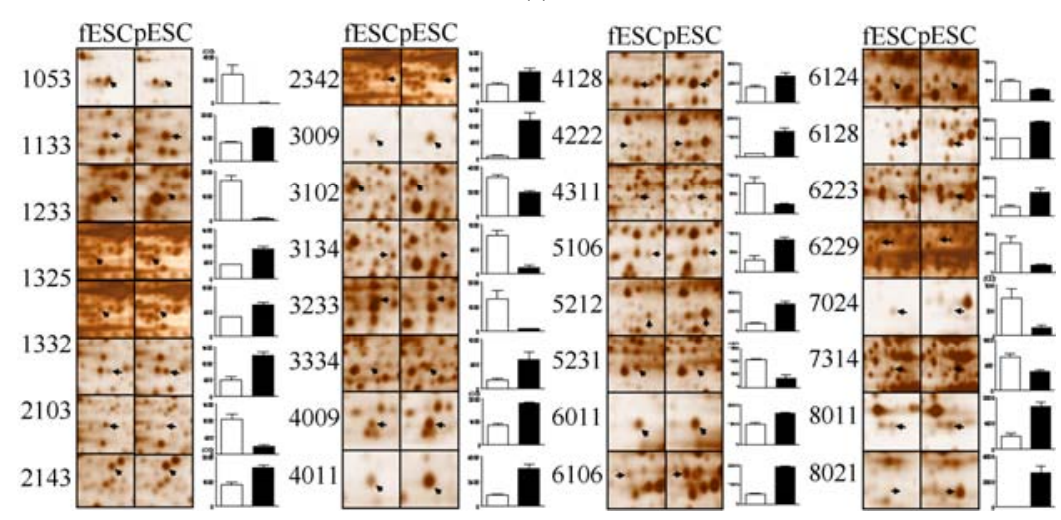

(b)

Figure 2. Comparative analysis of protein expression patterns between fESCs and pESCs. (a) Silver-stained 2-DE gel of fESC and pESC proteins. (b) Enlargement of 2-DE gel images of upregulated or downregulated proteins in fESCs and pESCs. The statistical data were obtained from 2-DE gels in three independent experiments $(P<0.05)$. Arrows indicate altered proteins in fESCs and pESCs. White bars, fESCs; black bars, pESCs. 
Table 2. Identification of differentially expressed proteins between fESCs and pESCs.

\begin{tabular}{|c|c|c|c|c|c|c|c|}
\hline \multirow{2}{*}{$\begin{array}{l}\text { Spot } \\
\text { No. }\end{array}$} & \multirow{2}{*}{$\begin{array}{c}\text { Fold } \\
\text { Change } \\
\text { (pES/fES) }\end{array}$} & \multirow{2}{*}{ Protein Name } & \multirow{2}{*}{ Peptide Sequence } & \multirow{2}{*}{$\begin{array}{l}\mathrm{SC} \\
(\%)\end{array}$} & \multicolumn{2}{|c|}{ Protein $\mathrm{pI} / \mathrm{MW}(\mathrm{kDa})$} & \multirow{2}{*}{$\begin{array}{l}\text { Accession } \\
\text { No. } \\
\text { /Database }\end{array}$} \\
\hline & & & & & Theoretical & Experimental & \\
\hline \multicolumn{8}{|c|}{ High-expression protein spots (relative to fESCs), (12) } \\
\hline 1053 & -51.53 & Unnamed protein product & DSNNLCLHFNPR & 11 & $5.19 / 11.6$ & $5.20 / 11.8$ & $\begin{array}{l}52890 / \mathrm{NC} \\
\mathrm{P} 48538 / \mathrm{SP}\end{array}$ \\
\hline 1233 & -22.05 & Annexin A5 & $\begin{array}{l}\text { GTVTDFPGFDGR VLTEIIASR } \\
\text { GAGTDDHTLIR }\end{array}$ & 10 & $4.83 / 35.7$ & $4.80 / 35.4$ & $\begin{array}{l}\text { 6753060/NC } \\
\mathrm{P} 48036 / \mathrm{SP}\end{array}$ \\
\hline 2143 & -4.61 & Chloride intracellular channel 1 & $\begin{array}{l}\text { YLSNAYAR EEFASTCPDDEEIE- } \\
\text { LAYEQVAR }\end{array}$ & 12 & $5.09 / 26.9$ & $5.30 / 30.1$ & $\begin{array}{c}\text { 15617203/NC } \\
\text { Q9Z1Q5/SP }\end{array}$ \\
\hline 3102 & -1.63 & Prohibitin & ILFRPVASQLPR & 4 & $5.57 / 29.8$ & $5.70 / 29.5$ & $6679299 / \mathrm{NC}$ \\
\hline 3134 & -6.73 & $\begin{array}{l}\text { Endoplasmic reticulum protein } \\
\text { ERp29 precursor }\end{array}$ & FDTQYPYGEK ILDQGEDFPASEMAR & 9 & $5.90 / 28.8$ & 6.10 .27 .3 & $\begin{array}{c}19526463 / \mathrm{NC} \\
\mathrm{P} 57759 / \mathrm{SP}\end{array}$ \\
\hline 3233 & -17.31 & Annexin A3 & $\begin{array}{l}\text { LTFDEYR NTPAFLAER GAGT- } \\
\text { DEFTLNR }\end{array}$ & 8 & $5.33 / 36.3$ & $5.70 / 38.8$ & $\begin{array}{l}\text { 7304887/NC } \\
\text { O35639/SP }\end{array}$ \\
\hline 4311 & -3.49 & Oat protein & $\begin{array}{l}\text { KTEQGPPSSEYIFER } \\
\text { VLPMNTGVEAGETACK }\end{array}$ & 7 & $6.19 / 48.3$ & $6.20 / 48.0$ & $\begin{array}{l}14198116 / \mathrm{NC} \\
\mathrm{P} 29758 / \mathrm{SP}\end{array}$ \\
\hline 5231 & -2.97 & $\begin{array}{l}\text { Acidic ribosomal } \\
\text { phosphoprotein } \mathrm{P} 0\end{array}$ & $\begin{array}{l}\text { GHLENNPALEK AGAIAP- } \\
\text { CEVTVPAQNTGLGPEK }\end{array}$ & 10 & $5.91 / 34.1$ & $6.40 / 37.5$ & $\begin{array}{l}6671569 / \mathrm{NC} \\
\mathrm{P} 14869 / \mathrm{SP}\end{array}$ \\
\hline 6124 & -1.80 & B-cell stimulating factor 3 & LGAETLPR & 3 & $8.70 / 25.2$ & $7.50 / 29.0$ & $\begin{array}{l}\text { 9910314/NC } \\
\text { Q9QZM3/SP }\end{array}$ \\
\hline 6229 & -3.76 & Steroid hormone receptor ERR1 & LVLSSLPK & 1 & $6.84 / 49.2$ & $7.30 / / 40.5$ & $\mathrm{O} 08580 / \mathrm{SP}$ \\
\hline 7024 & -4.64 & $\begin{array}{l}\text { Trafficking protein particle } \\
\text { complex } 5\end{array}$ & VLDALVAR & 4 & $9.69 / 20.7$ & $8.20 / 19.3$ & $29165850 / \mathrm{NC}$ \\
\hline 7314 & -1.77 & $\begin{array}{l}\text { Branched-chain amino acid } \\
\text { aminotransferase }\end{array}$ & $\begin{array}{l}\text { AGWGPPR LGGNYGPTVAVQR } \\
\text { TWGEFR }\end{array}$ & 7 & $7.60 / 39.7$ & $8.00 / 41.7$ & $\begin{array}{l}3298579 / \mathrm{NC} \\
\mathrm{O} 35855 / \mathrm{SP}\end{array}$ \\
\hline \multicolumn{8}{|c|}{ Low-expression protein spots (relative to fESCs), (20) } \\
\hline 1133 & +1.80 & $\begin{array}{l}\text { Ran-specific GTPase-activating } \\
\text { protein }\end{array}$ & FASENDLPEWK & 5 & $5.15 / 23.5$ & $5.30 / 27.3$ & P34022/SP \\
\hline 1325 & +2.11 & $\begin{array}{l}\text { Serine/threonine kinase receptor } \\
\text { associated protein }\end{array}$ & FSPDGELYASGSEDGTLR & 5 & $4.99 / 38.4$ & $5.20 / 42.6$ & $\begin{array}{l}6755682 / \mathrm{NC} \\
\mathrm{Q} 9 \mathrm{Z} 1 \mathrm{Z2} / \mathrm{SP}\end{array}$ \\
\hline 1332 & +1.64 & Galactokinase 1 & $\begin{array}{l}\text { GYALLIDCR LAVLITNSNVR } \\
\text { HSLGSSEYPVR }\end{array}$ & 7 & $5.17 / 42.2$ & $5.20 / 43.8$ & $\begin{array}{l}\text { 16741595/NC } \\
\text { Q9R0N0/SP }\end{array}$ \\
\hline 2103 & +2.48 & Ubiquitin thiolesterase PGP9.5 & $\begin{array}{l}\text { LGVAGQWR NEAIQAAHDSVA- } \\
\text { QEGQCR }\end{array}$ & 11 & $5.12 / 24.7$ & $5.30 / 25.2$ & $\begin{array}{l}\text { 92934/NC } \\
\text { Q9R0P9/SP }\end{array}$ \\
\hline 2213 & +1.80 & Spermidine synthase & $\begin{array}{l}\text { YQDILVFR VLIIGGGDGGVLR } \\
\text { AAFVLPEFTR }\end{array}$ & 10 & $5.31 / 33.9$ & $5.40 / 35.7$ & $\begin{array}{l}\text { 6678131/NC } \\
\text { Q9R0N0/SP }\end{array}$ \\
\hline 2342 & +1.77 & $\begin{array}{l}\text { SGT1, suppressor of G2 allele } \\
\text { of SKP1 }\end{array}$ & $\begin{array}{l}\text { ALEQNPDDAQYYCQR } \\
\text { SLELNPNNCTALLR }\end{array}$ & 8 & $5.32 / 38.1$ & $5.40 / 43.0$ & $\begin{array}{l}23956176 / \mathrm{NC} \\
\mathrm{Q} 9 \mathrm{CX} 34 / \mathrm{SP}\end{array}$ \\
\hline 3009 & +14.57 & Stathmin 1 & ASGQAFELILSPR & 8 & $5.76 / 17.2$ & $5.90 / 17.5$ & $\begin{array}{l}\text { 9789995/NC } \\
\text { P54227/SP }\end{array}$ \\
\hline
\end{tabular}




\begin{tabular}{|c|c|c|c|c|c|c|c|}
\hline 3334 & +3.43 & Steroid hormone receptor ERR1 & LVLSSLPK & 1 & $6.84 / 49.2$ & $6.00 / 41.8$ & $131224731 / \mathrm{NC}$ \\
\hline 4009 & +2.16 & DJ-1 protein & $\begin{array}{l}\text { VTVAGLAGKDPVQCSR } \\
\text { MMNGSHYSYSESR }\end{array}$ & 15 & $6.32 / 19.9$ & $6.20 / 22.5$ & $\begin{array}{l}\text { 16924002/NC } \\
\text { Q99LX0/SP }\end{array}$ \\
\hline 4011 & +3.36 & $\mathrm{Cu} / \mathrm{Zn}$-superoxide dismutase & KHGGPADEER VISLSGEHSIIGR & 14 & $6.23 / 15.9$ & $6.20 / 16.0$ & $\begin{array}{l}201006 / \mathrm{NC} \\
\mathrm{P} 08228 / \mathrm{SP}\end{array}$ \\
\hline 4128 & +1.73 & Heat shock protein 27 & $\begin{array}{l}\text { LFDQAFGVPR AV- } \\
\text { TQSAEITIPVTFEAR }\end{array}$ & 13 & $6.12 / 22.8$ & $6.30 / 24.6$ & $\begin{array}{l}204665 / \mathrm{NC} \\
\mathrm{P} 14602 / \mathrm{SP}\end{array}$ \\
\hline 4222 & +8.40 & Estrogen-related receptor alpha & LV LVLSSLPK & 1 & $5.77 / 45.0$ & $6.30 / 33.2$ & $\begin{array}{l}\text { 6679693/NC } \\
\text { O08580/SP }\end{array}$ \\
\hline 5106 & +2.89 & $\begin{array}{l}\text { Acyl-protein thioesterase } 1 \text { (Lyso- } \\
\text { phospholipase I) }\end{array}$ & ASFSQGPINSANR & 5 & $6.14 / 24.6$ & $6.40 / 23.3$ & $\mathrm{P} 97823 / \mathrm{SP}$ \\
\hline 5212 & +3.50 & Uridine phosphorylase 1 & $\begin{array}{l}\text { FVCVGGSSSR EYPNICAGTDR } \\
\text { MLYHAR CSNITIIR }\end{array}$ & 11 & $6.12 / 34.0$ & $6.50 / 33.3$ & $\begin{array}{l}6678515 / \mathrm{NC} \\
\mathrm{P} 52624 / \mathrm{SP}\end{array}$ \\
\hline 6011 & +1.60 & $\begin{array}{l}\text { Similar to basic transcription factor } \\
3\end{array}$ & VQASLAANTFTITGHAETK & 34 & $7.85 / 19.4$ & $7.60 / 18.5$ & $51762066 / \mathrm{NC}$ \\
\hline 6106 & +3.87 & GTP-binding nuclear protein Ran & $\begin{array}{l}\text { FNVWDTAGQEK NVPNWHR VCE- } \\
\text { NIPIVLCGNK SIVFHR }\end{array}$ & 17 & $7.01 / 24.4$ & $7.00 / 24.5$ & $\mathrm{P} 62827 / \mathrm{SP}$ \\
\hline 6128 & +1.82 & $\begin{array}{l}\text { Glutathione S-transferase, } \\
\text { alpha } 4\end{array}$ & $\begin{array}{l}\text { EKEESYDLILSR FLQPGSQR } \\
\text { KPPPDGPYVEVVR }\end{array}$ & 14 & $6.77 / 25.5$ & $7.10 / 23.3$ & $\begin{array}{l}\text { 6754082/NC } \\
\mathrm{P} 24472 / \mathrm{SP}\end{array}$ \\
\hline 6223 & +2.67 & $\begin{array}{l}\text { L-lactate dehydrogenase } \\
\text { chain } \mathrm{M}\end{array}$ & $\begin{array}{l}\text { VIGSGCNLDSAR SLNPELGTDAD- } \\
\text { KEQWK SADTLWGIQK }\end{array}$ & 11 & $7.62 / 36.4$ & $7.50 / 37.6$ & $\begin{array}{l}\text { 65923/NC } \\
\mathrm{P} 06151 / \mathrm{SP}\end{array}$ \\
\hline 8011 & +3.16 & $\begin{array}{l}\text { Proteasome (prosome, macropain) } \\
\text { subunit, beta type } 5\end{array}$ & $\begin{array}{l}\text { RGPGLYYVDSEGNR GPGLY- } \\
\text { YVDSEGNR RAIYQATYR AIYQATYR } \\
\text { DAYSGGAVNLYHVR }\end{array}$ & 14 & $6.52 / 28.5$ & $8.50 / 21.3$ & $\begin{array}{l}\text { 6755204/NC } \\
\mathrm{O} 55234 / \mathrm{SP}\end{array}$ \\
\hline 8021 & +413.80 & Hypothetical protein & VGPMLSPR & 4 & $9.69 / 21.0$ & $8.50 / 19.6$ & $\begin{array}{l}51767674 / \mathrm{NC} \\
\text { Q7TQH0/SP }\end{array}$ \\
\hline
\end{tabular}

pES/fES: pESCs/fESCs.

Table 3. Identification of differentially expressed proteins between fESCs and aESC.

\begin{tabular}{|c|c|c|c|c|c|c|c|}
\hline \multirow{2}{*}{$\begin{array}{l}\text { Spot } \\
\text { No. }\end{array}$} & \multirow{2}{*}{$\begin{array}{c}\text { Fold } \\
\text { Change } \\
(\mathrm{aES} / \mathrm{fES})\end{array}$} & \multirow{2}{*}{ Protein Name } & \multirow{2}{*}{ Peptide Sequence } & \multirow{2}{*}{$\begin{array}{l}\mathrm{SC} \\
(\%)\end{array}$} & \multicolumn{2}{|c|}{ Protein pI/MW (kDa) } & \multirow{2}{*}{$\begin{array}{l}\text { Accession No } \\
\text { /Database }\end{array}$} \\
\hline & & & & & Theoretical & Experimental & \\
\hline \multicolumn{8}{|c|}{ High-expression protein spots (relative to fESCs), (10) } \\
\hline 1053 & -37.68 & Unnamed protein & DSNNLCLHFNPR & 11 & $5.19 / 11.6$ & $5.20 / 11.8$ & $\begin{array}{l}52890 / \mathrm{NC} \\
\mathrm{P} 48538 / \mathrm{SP}\end{array}$ \\
\hline 1233 & -3.23 & Annexin A5 & $\begin{array}{l}\text { GTVTDFPGFDGR VLTEIIASR } \\
\text { GAGTDDHTLIR }\end{array}$ & 10 & $4.83 / 35.7$ & $4.80 / 35.4$ & $\begin{array}{l}\text { 6753060/NC } \\
\mathrm{P} 48036 / \mathrm{SP}\end{array}$ \\
\hline 2143 & -3.51 & $\begin{array}{l}\text { Chloride intracellular } \\
\text { channel } 1\end{array}$ & $\begin{array}{l}\text { YLSNAYAR } \\
\text { EEFASTCPDDEEIELAYEQVAR }\end{array}$ & 12 & $5.09 / 26.9$ & $5.30 / 30.1$ & $\begin{array}{l}\text { 15617203/NC } \\
\text { Q9Z1Q5/SP }\end{array}$ \\
\hline 3134 & -13.01 & $\begin{array}{l}\text { Endoplasmic reticulum } \\
\text { protein ERp29 precursor }\end{array}$ & $\begin{array}{l}\text { FDTQYPYGEK } \\
\text { ILDQGEDFPASEMAR }\end{array}$ & 9 & $5.90 / 28.8$ & 6.10 .27 .3 & $\begin{array}{l}\text { 19526463/NC } \\
\text { P57759/SP }\end{array}$ \\
\hline 3233 & -5.48 & Annexin A3 & $\begin{array}{l}\text { LTFDEYR NTPAFLAER } \\
\text { GAGTDEFTLNR }\end{array}$ & 8 & $5.33 / 36.3$ & $5.70 / 38.8$ & $\begin{array}{c}7304887 / \mathrm{NC} \\
\mathrm{O} 35639 / \mathrm{SP}\end{array}$ \\
\hline 3307 & -1.61 & Calponin 3, acidic & $\begin{array}{l}\text { RFDEGK CASQAGMTAYGTR GAS- } \\
\text { QAGMLAPGTR GMSVYGLGR }\end{array}$ & 12 & $5.46 / 36.4$ & $5.80 / 41.6$ & $\begin{array}{l}55391513 / \mathrm{NC} \\
\text { Q9DAW9/SP }\end{array}$ \\
\hline
\end{tabular}




\begin{tabular}{|c|c|c|c|c|c|c|c|}
\hline 3312 & -1.50 & Unnamed protein & APIQWEER CSDFTEEICR & 4 & $6.27 / 39.6$ & $5.90 / 41.4$ & $26339056 / \mathrm{NC}$ \\
\hline 4311 & -2.16 & Oat protein & $\begin{array}{l}\text { KTEQGPPSSEYIFER } \\
\text { VLPMNTGVEAGETACK }\end{array}$ & 7 & $6.19 / 48.3$ & $6.20 / 48.0$ & $\begin{array}{l}\text { 14198116/NC } \\
\text { P29758/SP }\end{array}$ \\
\hline 5231 & -5.55 & $\begin{array}{l}\text { Acidic ribosomal } \\
\text { phosphoprotein P0 }\end{array}$ & $\begin{array}{l}\text { GHLENNPALEK AGAIAP- } \\
\text { CEVTVPAQNTGLGPEK }\end{array}$ & 10 & $5.91 / 34.1$ & $6.40 / 37.5$ & $\begin{array}{l}\text { 6671569/NC } \\
\mathrm{P} 14869 / \mathrm{SP}\end{array}$ \\
\hline 5309 & -1.94 & $\begin{array}{l}\text { Heterogeneous nuclear } \\
\text { ribonucleoprotein A/B }\end{array}$ & EVYQQQQYGSGGR & 4 & $7.68 / 30.8$ & $6.50 / 43.6$ & Q99020/SP \\
\hline \multicolumn{4}{|c|}{ Low-expression protein spots (relative to fESCs), } & \multicolumn{3}{|l|}{$(18)$} & \\
\hline 1109 & +2.97 & $14-3-3$ protein gamma & $\begin{array}{l}\text { LAEQAER NVTELNEPLSNEER } \\
\text { MKGDYYR }\end{array}$ & 11 & $4.80 / 28.3$ & $4.80 / 28.1$ & $\begin{array}{l}3065929 / \mathrm{NC} \\
\mathrm{P} 68510 / \mathrm{SP}\end{array}$ \\
\hline 1325 & +1.89 & $\begin{array}{l}\text { Serine/threonine kinase } \\
\text { receptor-associated protein }\end{array}$ & FSPDGELYASGSEDGTLR & 5 & $4.99 / 38.4$ & $5.20 / 42.6$ & $\begin{array}{l}\text { 6755682/NC } \\
\mathrm{Q} 9 \mathrm{Z} 1 \mathrm{Z2} / \mathrm{SP}\end{array}$ \\
\hline 1331 & +2.05 & $\begin{array}{l}\text { B-cell stimulating factor-3 } \\
\text { precursor (BSF-3) (Novel } \\
\text { neurotrophin-1) (NNT-1) }\end{array}$ & LGAETLPR & 3 & $8.70 / 25.2$ & $5.20 / 42.0$ & Q9QZM3/SP \\
\hline 2213 & +1.76 & Spermidine synthase & $\begin{array}{l}\text { YQDILVFR VLIIGGGDGGVLR } \\
\text { AAFVLPEFTR }\end{array}$ & 10 & $5.31 / 33.9$ & $5.40 / 35.7$ & $\begin{array}{l}\text { 6678131/NC } \\
\text { Q9R0N0/SP }\end{array}$ \\
\hline 2221 & +1.83 & $\begin{array}{l}\text { Similar to hypothetical } \\
\text { protein MGC36907 }\end{array}$ & NKYEDEINKR & 3 & $5.42 / 36.2$ & $5.50 / 36.3$ & $34868312 / \mathrm{NC}$ \\
\hline 2317 & +2.17 & $\begin{array}{l}\text { Ubiquitin-like } 1 \text { activating } \\
\text { enzyme E1A }\end{array}$ & VDQICHR & 2 & $5.24 / 38.5$ & $5.40 / 43.7$ & Q9R1T2/SP \\
\hline 4009 & +2.15 & DJ-1 protein & $\begin{array}{l}\text { VTVAGLAGKDPVQCSR } \\
\text { MMNGSHYSYSESR }\end{array}$ & 15 & $6.32 / 19.9$ & $6.20 / 22.5$ & $\begin{array}{l}16924002 / \mathrm{NC} \\
\mathrm{Q} 99 \mathrm{LX} 0 / \mathrm{SP}\end{array}$ \\
\hline 4011 & +2.47 & $\begin{array}{l}\mathrm{Cu} / \mathrm{Zn} \text {-superoxide } \\
\text { dismutase }\end{array}$ & KHGGPADEER VISLSGEHSIIGR & 14 & $6.23 / 15.9$ & $6.20 / 16.0$ & $\begin{array}{l}\text { 201006/NC } \\
\mathrm{P} 08228 / \mathrm{SP}\end{array}$ \\
\hline 4222 & +5.09 & $\begin{array}{l}\text { Estrogen-related } \\
\text { receptor alpha }\end{array}$ & LV LVLSSLPK & 1 & $5.77 / 45.0$ & $6.30 / 33.2$ & $\begin{array}{c}6679693 / \mathrm{NC} \\
\mathrm{O} 08580 / \mathrm{SP}\end{array}$ \\
\hline 4305 & +1.76 & eIF3-p44 & $\begin{array}{l}\text { CPYKDTLGPMQK } \\
\text { CPYKDTLGPMQK }\end{array}$ & 3 & $6.08 / 35.3$ & $6.10 / 47.8$ & $\begin{array}{l}\text { 4097873/NC } \\
\text { Q9Z1D1/SP }\end{array}$ \\
\hline 5212 & +3.03 & $\begin{array}{l}\text { Uridine } \\
\text { phosphorylase } 1\end{array}$ & $\begin{array}{l}\text { FVCVGGSSSR EYPNICAGTDR } \\
\text { MLYHAR CSNITIIR }\end{array}$ & 11 & $6.12 / 34.0$ & $6.50 / 33.3$ & $\begin{array}{l}\text { 6678515/NC } \\
\mathrm{P} 52624 / \mathrm{SP}\end{array}$ \\
\hline 6011 & +1.56 & $\begin{array}{l}\text { Similar to basic } \\
\text { transcription factor } 3\end{array}$ & VQASLAANTFTITGHAETK & 34 & $7.85 / 19.4$ & $7.60 / 18.5$ & $51762066 / \mathrm{NC}$ \\
\hline 6106 & +1.95 & $\begin{array}{l}\text { GTP-binding nuclear } \\
\text { protein Ran }\end{array}$ & $\begin{array}{l}\text { FNVWDTAGQEK NVPNWHR VCE- } \\
\text { NIPIVLCGNK SIVFHR }\end{array}$ & 17 & $7.01 / 24.4$ & $7.00 / 24.5$ & $\mathrm{P} 62827 / \mathrm{SP}$ \\
\hline 6128 & +1.88 & $\begin{array}{l}\text { Glutathione S-transferase, } \\
\text { alpha } 4\end{array}$ & $\begin{array}{l}\text { EKEESYDLILSR FLQPGSQR } \\
\text { KPPPDGPYVEVVR }\end{array}$ & 14 & $6.77 / 25.5$ & $7.10 / 23.3$ & $\begin{array}{l}\text { 6754082/NC } \\
\mathrm{P} 24472 / \mathrm{SP}\end{array}$ \\
\hline 7011 & +3.06 & $\begin{array}{l}\text { Thymidylate kinase; } \\
\text { TMK }\end{array}$ & YAFSGVAFTGAK GEFGLER & 8 & $9.16 / 25.5$ & $8.00 / 22.8$ & $\begin{array}{l}1836042 / \mathrm{NC} \\
\mathrm{P} 97930 / \mathrm{SP}\end{array}$ \\
\hline 7023 & +1.63 & $\begin{array}{l}\text { Component } \mathrm{C} 5 \text { of } \\
\text { proteasome }\end{array}$ & LSEGFSIHTR DVFISAAER & 8 & $8.29 / 24.6$ & $8.20 / 23.1$ & $\begin{array}{l}1165123 / \mathrm{NC} \\
\mathrm{O} 09061 / \mathrm{SP}\end{array}$ \\
\hline 8011 & +2.74 & $\begin{array}{l}\text { Proteasome (prosome, } \\
\text { macropain) subunit, } \\
\text { beta type } 5\end{array}$ & $\begin{array}{l}\text { RGPGLYYVDSEGNR GPGLY- } \\
\text { YVDSEGNR RAIYQATYR AIY- } \\
\text { QATYR DAYSGGAVNLYHVR }\end{array}$ & 14 & $6.52 / 28.5$ & $8.50 / 21.3$ & $\begin{array}{l}\text { 6755204/NC } \\
\text { O55234/SP }\end{array}$ \\
\hline 8021 & +562.88 & Hypothetical protein & VGPMLSPR & 4 & $9.69 / 21.0$ & $8.50 / 19.6$ & $\begin{array}{l}51767674 / \mathrm{NC} \\
\mathrm{Q} 7 \mathrm{TQH} / \mathrm{SP}\end{array}$ \\
\hline
\end{tabular}

aES/fES: aESCs/fESCs. 
Table 4. Summary of differentially expressed proteins between pESCs and aESCs.

\begin{tabular}{|c|c|c|c|c|c|c|c|}
\hline \multirow{2}{*}{$\begin{array}{l}\text { Spot } \\
\text { No. }\end{array}$} & \multirow{2}{*}{$\begin{array}{c}\text { Fold } \\
\text { Change } \\
(\mathrm{aES} / \mathrm{pES})\end{array}$} & \multirow{2}{*}{ Protein Name } & \multirow{2}{*}{ Peptide Sequence } & \multirow{2}{*}{$\begin{array}{l}\mathrm{SC} \\
(\%)\end{array}$} & \multicolumn{2}{|c|}{ Protein $\mathrm{pI} / \mathrm{MW}(\mathrm{kDa})$} & \multirow{2}{*}{$\begin{array}{l}\text { Accession No. } \\
\text { /Database }\end{array}$} \\
\hline & & & & & Theoretical & Experimental & \\
\hline \multicolumn{8}{|c|}{ High-expression protein spots (relative to pESCs), (8) } \\
\hline 3009 & -2.13 & Stathmin 1 & ASGQAFELILSPR & 8 & $5.76 / 17.2$ & $5.90 / 17.5$ & $\begin{array}{c}9789995 / \mathrm{NC} \\
\mathrm{P} 54227 / \mathrm{SP}\end{array}$ \\
\hline 3112 & -2.00 & Heat shock protein beta 1 & $\begin{array}{l}\text { LFDQAFGVPR } \\
\text { AVTQSAEITIPVTFEAR }\end{array}$ & 12 & $6.45 / 22.8$ & $5.90 / 25.2$ & $\begin{array}{l}\text { 7305173/NC } \\
\mathrm{P} 14602 / \mathrm{SP}\end{array}$ \\
\hline 3334 & -2.27 & $\begin{array}{l}\text { Steroid hormone receptor } \\
\text { ERR1 }\end{array}$ & LVLSSLPK & 1 & $6.84 / 49.2$ & $6.00 / 41.8$ & $131224731 / \mathrm{NC}$ \\
\hline 4222 & -1.65 & $\begin{array}{l}\text { Estrogen related } \\
\text { receptor alpha }\end{array}$ & LVLSSLPK & 1 & $5.77 / 45.0$ & $6.30 / 33.2$ & $\begin{array}{l}6679693 / \mathrm{NC} \\
\mathrm{O} 08580 / \mathrm{SP}\end{array}$ \\
\hline 5231 & -2.38 & $\begin{array}{l}\text { Acidic ribosomal } \\
\text { phosphoprotein P0 }\end{array}$ & $\begin{array}{l}\text { GHLENNPALEK } \\
\text { AGAIAPCEVTVPAQNTGLGPEK }\end{array}$ & 10 & $5.91 / 34.1$ & $6.40 / 37.5$ & $\begin{array}{l}\text { 6671569/NC } \\
\mathrm{P} 14869 / \mathrm{SP}\end{array}$ \\
\hline 6106 & -1.98 & $\begin{array}{l}\text { GTP-binding nuclear } \\
\text { protein Ran }\end{array}$ & $\begin{array}{l}\text { FNVWDTAGQEK NVPNWHR } \\
\text { VCENIPIVLCGNK SIVFHR }\end{array}$ & 17 & $7.01 / 24.4$ & $7.00 / 24.5$ & $\mathrm{P} 62827 / \mathrm{SP}$ \\
\hline 6223 & -1.90 & $\begin{array}{l}\text { L-lactate dehydrogenase } \\
\text { chain } \mathrm{M}\end{array}$ & $\begin{array}{l}\text { VIGSGCNLDSAR } \\
\text { SLNPELGTDADKEQWK SADTLWGIQK }\end{array}$ & 11 & $7.62 / 36.4$ & $7.50 / 37.6$ & $\begin{array}{l}\text { 65923/NC } \\
\mathrm{P} 06151 / \mathrm{SP}\end{array}$ \\
\hline 8021 & -1.90 & Hypothetical protein & VGPMLSPR & 4 & $9.69 / 21.0$ & $8.50 / 19.6$ & $\begin{array}{c}51767674 / \mathrm{NC} \\
\text { Q7TQH0/SP }\end{array}$ \\
\hline \multicolumn{8}{|c|}{ Low-expression protein spots (relative to pESCs), (9) } \\
\hline 1233 & +4.88 & Annexin A5 & $\begin{array}{l}\text { GTVTDFPGFDGR VLTEIIASR } \\
\text { GAGTDDHTLIR }\end{array}$ & 10 & $4.83 / 35.7$ & $4.80 / 35.4$ & $\begin{array}{l}\text { 6753060/NC } \\
\mathrm{P} 48036 / \mathrm{SP}\end{array}$ \\
\hline 4311 & +1.62 & Oat protein & $\begin{array}{l}\text { KTEQGPPSSEYIFER } \\
\text { VLPMNTGVEAGETACK }\end{array}$ & 7 & $6.19 / 48.3$ & $6.20 / 48.0$ & $\begin{array}{l}14198116 / \mathrm{NC} \\
\mathrm{P} 29758 / \mathrm{SP}\end{array}$ \\
\hline 6124 & +2.00 & $\begin{array}{l}\text { B-cell stimulating } \\
\text { factor } 3\end{array}$ & LGAETLPR & 3 & $8.70 / 25.2$ & $7.50 / 29.0$ & $\begin{array}{l}\text { 9910314/NC } \\
\text { Q9QZM3/SP }\end{array}$ \\
\hline 6126 & +1.52 & Unnamed protein & $\begin{array}{l}\text { FNVWDTAGQEKNVPNWHR } \\
\text { VCENIPIVLCGNK SIVFHR }\end{array}$ & 17 & $7.01 / 24.3$ & $7.60 / 23.7$ & $\begin{array}{l}12846283 / \mathrm{NC} \\
\mathrm{P} 62827 / \mathrm{SP}\end{array}$ \\
\hline 7011 & +1.59 & $\begin{array}{l}\text { Thymidylate kinase; } \\
\text { TMK }\end{array}$ & YAFSGVAFTGAK GEFGLER & 8 & $9.16 / 25.5$ & $8.00 / 22.8$ & $\begin{array}{l}1836042 / \mathrm{NC} \\
\mathrm{P} 97930 / \mathrm{SP}\end{array}$ \\
\hline 7024 & +1.87 & $\begin{array}{l}\text { Trafficking protein } \\
\text { particle complex } 5\end{array}$ & VLDALVAR & 4 & $9.69 / 20.7$ & $8.20 / 19.3$ & $29165850 / \mathrm{NC}$ \\
\hline 7314 & +1.59 & $\begin{array}{l}\text { Branched-chain amino } \\
\text { acid aminotransferase }\end{array}$ & $\begin{array}{l}\text { AGWGPPR LGGNYGPTVAVQR } \\
\text { TWGEFR }\end{array}$ & 7 & $7.60 / 39.7$ & $8.00 / 41.7$ & $\begin{array}{l}3298579 / \mathrm{NC} \\
\mathrm{O} 35855 / \mathrm{SP}\end{array}$ \\
\hline 8107 & +1.63 & Unnamed protein & FDPENPQTLR & 5 & $9.36 / 18.2$ & $8.50 / 23.6$ & $12845642 / \mathrm{NC}$ \\
\hline 8212 & +1.65 & $\begin{array}{l}\text { Heterogeneous nuclear } \\
\text { ribonucleoprotein A2/B1 }\end{array}$ & $\begin{array}{l}\text { EKEQFRK NYYEQWGK } \\
\text { GGNFGFGDSR GGNFGFGDSR } \\
\text { NMGGPYGGGNYGPGGSGGSGGYGGR }\end{array}$ & 19 & $8.67 / 35.9$ & $8.70 / 35.6$ & $\begin{array}{l}3329498 / \mathrm{NC} \\
\mathrm{O} 88569 / \mathrm{SP}\end{array}$ \\
\hline
\end{tabular}

aES/pES: aESCs/pESCs. 


\subsection{Identification of Proteins in fESCs, pESCs and aESCs}

Table 2 lists the majority of the protein spots displaying different protein expression in fESCs and pESCs. There are 32 spots with significant differences in post-intensities between fESCs and pESCs (Figure 2 (b)). Among these 32, 12 were expressed at significantly higher levels and 20 were expressed at significantly lower levels in fESCs than in pESCs. The identities of the 32 proteins were determined by comparing the recorded masses of fingerprint peptides with the theoretical peptide masses derived from known mouse peptides in the protein database.

Similarly, Table 3 and $\mathbf{4}$ show proteins that were differentially displayed between fESCs vs. aESCs and pESCs vs. aESCs, respectively. Individual protein spots for these groups are shown in Figure 3(b) and Figure 4(b). Ten out of the 28 proteins differentially expressed in fESCs vs. aESCs were decreased in fESCs as compared with pESCs, and 8 out of the 17 proteins differentially expressed in pESCs vs. aESCs were decreased in pESCs as compared with aESCs. In contrast, 18 and 9 proteins were increased in expression for fESCs vs. aESCs and pESCs vs. aESCs, respectively.
fESC

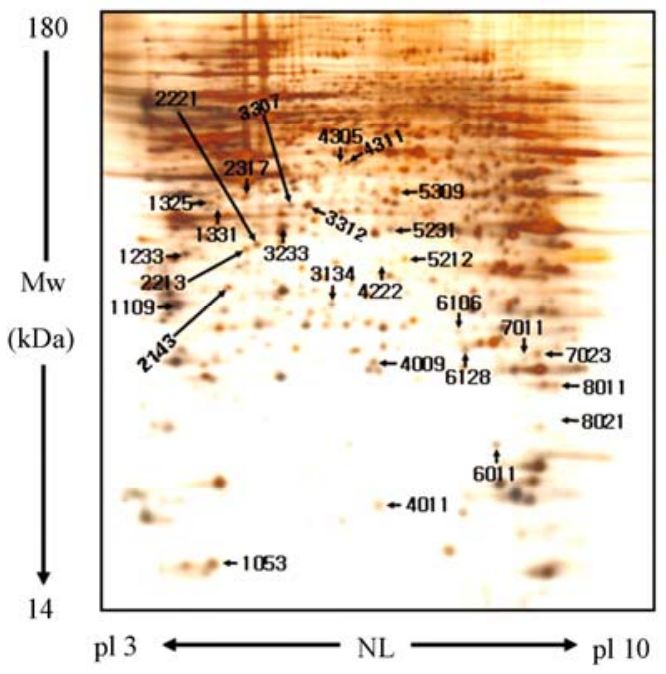

$\mathrm{aESC}$

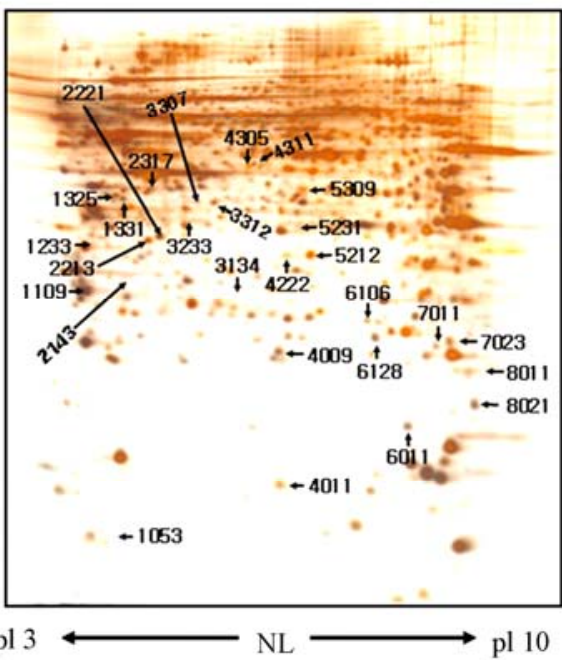

(a)

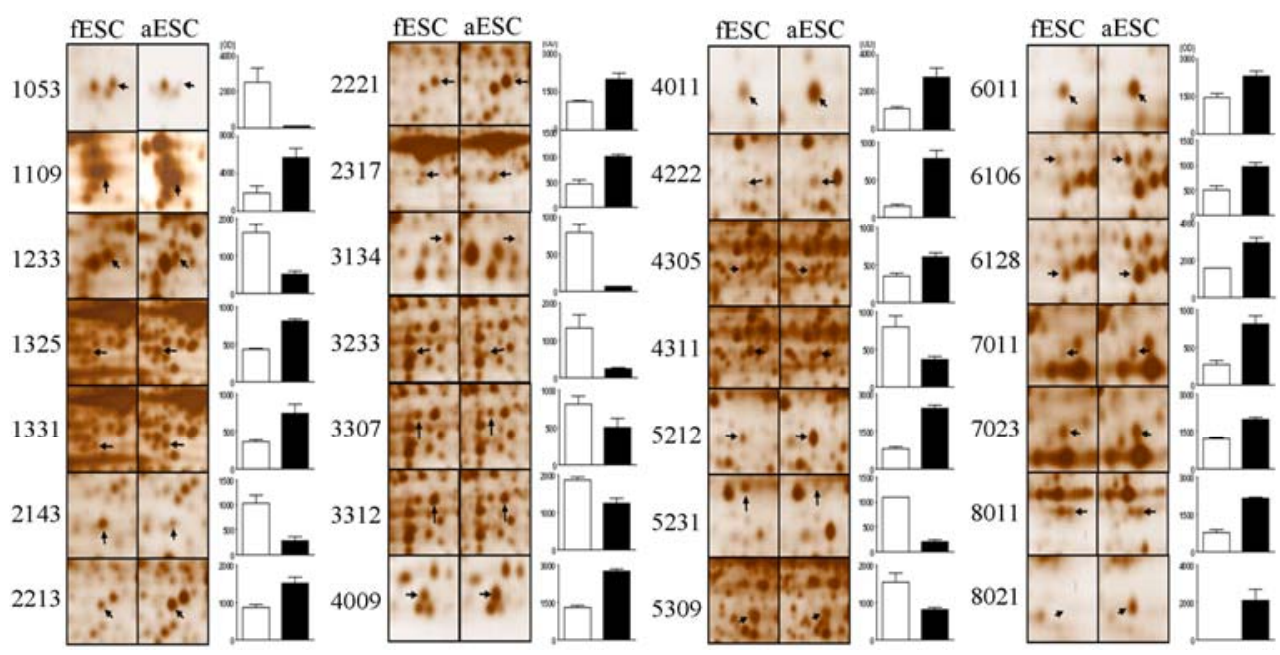

(b)

Figure 3. Comparative analysis of protein expression patterns between fESCs and aESCs. (a) Silver-stained 2-DE gel of fESC and aESC proteins. (b) Enlargement of 2-DE gel images of upregulated or downregulated proteins in fESCs and aESCs. The statistical data were obtained from 2 -DE gels in three independent experiments $(P<0.05)$. Arrows indicate altered proteins in fESCs and aESCs. White bars, fESCs; black bars, aESCs. 

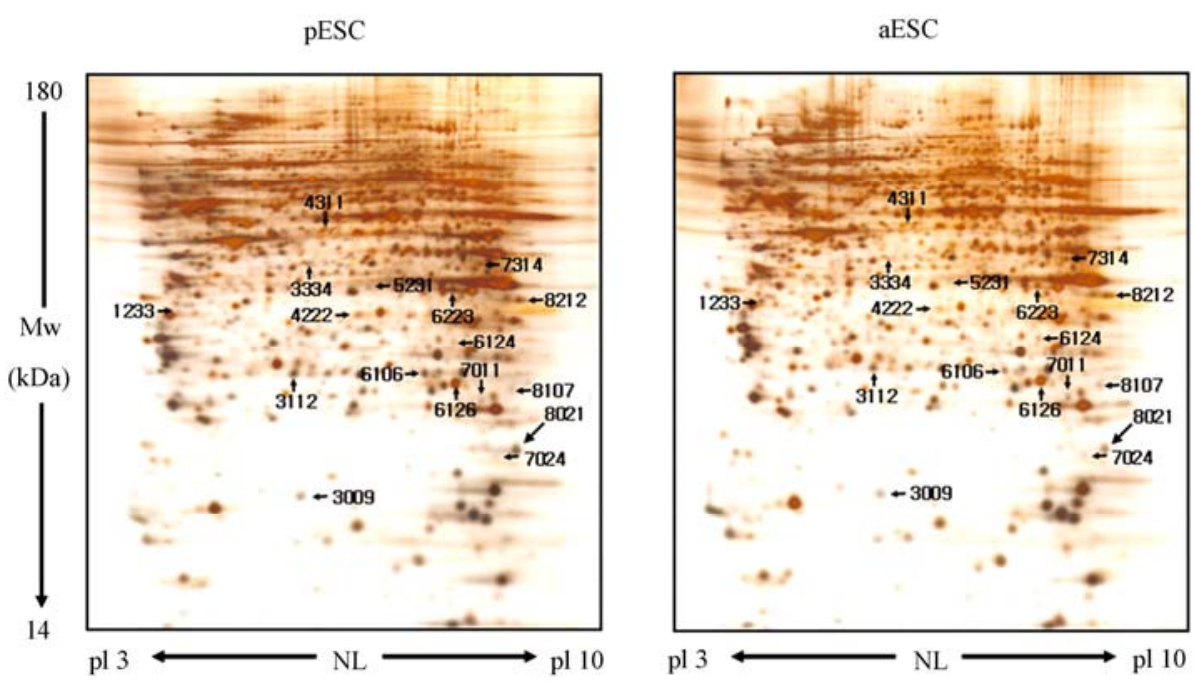

(a)
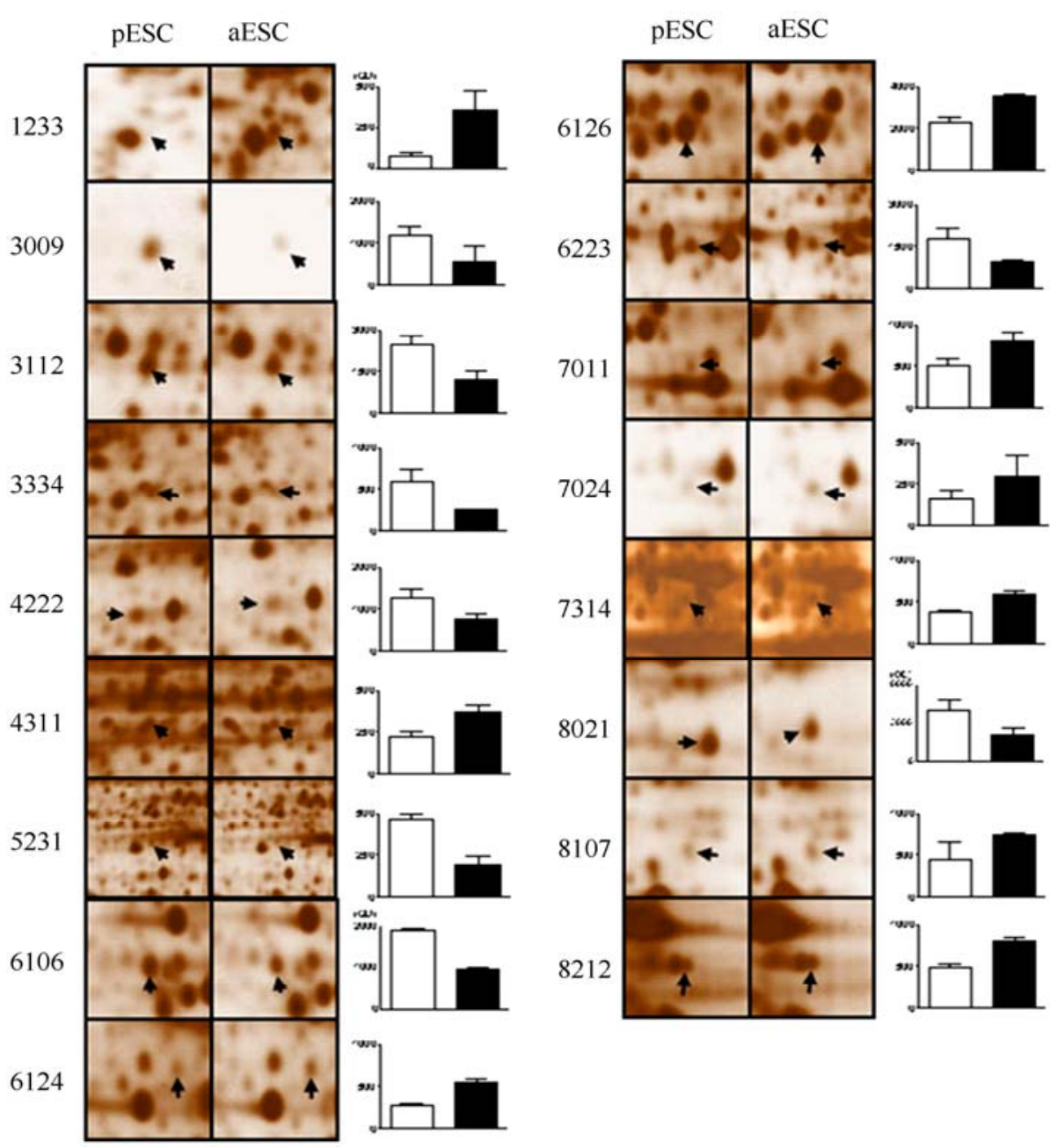

(b)

Figure 4. Comparative analysis of protein expression patterns between pESCs and aESCs. (a) Silver-stained 2-DE gel of pESC and aESC proteins. (b) Enlargement of 2-DE gel images of upregulated or downregulated proteins in pESCs and aESCs. The statistical data were obtained from 2-DE gels in three independent experiments $(P<0.05)$. Arrows indicate altered proteins in pESCs and aESCs. White bars, pESCs; black bars, aESCs. 


\section{4. mRNA and Protein Expression}

To investigate the changes in gene expression at the mRNA level, some proteins identified by MS were verified by real time RT-PCR to detect mRNA transcription (Figure 5 (a)-(c)). First, transcription levels were determined for eight protein candidates displaying differential expression in 2-DE. Four of these exhibited increased expression (Figure 5 (a)) and the other four exhibited reduced expression (Figure 5 (b)) in fESCs compared with both pESCs and aESCs. Additionally, apoptosis related four genes that were not identified by MS were also analyzed: $B c l-x L$, Baculoviral IAP repeat-containing 5 (Birc5, Survivin), Caspase 3 (Casp3) and BCL2-associated X protein (Bax, Figure 5 (c)). As seen in Figure 5, analyses of Annexin A5 (Anxa5), Chloride intracellular channel 1 (Clic1) and Spermidine synthase (Srm) mRNA (Figure 5 (a) \& (b)) showed the same expression patterns as the 2-DE results, i.e., the mRNA expression of Anxa5 and Clic1 was higher in fESCs than in pESCs and aESCs, and, SRM was low expressed in the fESCs compared with pESCS and aESCs. In addition, we confirmed ANXA5, CLIC1 and SRM protein expression by Western blot analysis, and these expression patterns were in agreement with the mRNA analyses (Figure 5 (b)). Endoplasmic reticulum protein ERp29 precursor (Erp29) and $\mathrm{Cu} / \mathrm{Zn}$-superoxide dismutase (Sod1) were increased and reduced in expression, respectively, in fESCs compared with pESCs, though no differences were observed between fESCs and aESCs. For three other candidates, Acidic ribosomal phosphoprotein P0 (Po protein), Serine/threonine kinase receptor associated protein (Strap) and Estrogen-related receptor alpha (Esrra), no differences were observed among the three types of ESCs (Figure 5 (a) \& (b)). For the apoptosis related genes, the anti-apoptotic gene $B c l-x L$ was highly expressed in the fESCs compared with the pESCs and aESCs; in contrast, the pro-apoptotic gene Bax was higher in the pESCs and aESCs than in the fESCs (Figure $5(\mathrm{c})$ ).

\section{DISCUSSION}

Embryonic stem cells derived from fertilized, androgenetic and parthenogenetic blastocyst (fESCs, aESCs and pESCS, respectively) were established and wellcharacterized by Dr. Wakayama. All ESC lines established in Dr. Wakayama's laboratory were shown positive for ESC-specific markers, and negative for differentiation markers [14-16]. We further performed for pluripotency/differentiation and sex analysis using RT- PCR or genomic DNA PCR. fESCs, aESCs and pESCs which were used to microarray were shown positive for ESC-specific marker genes such as Oct4 and Nanog, and

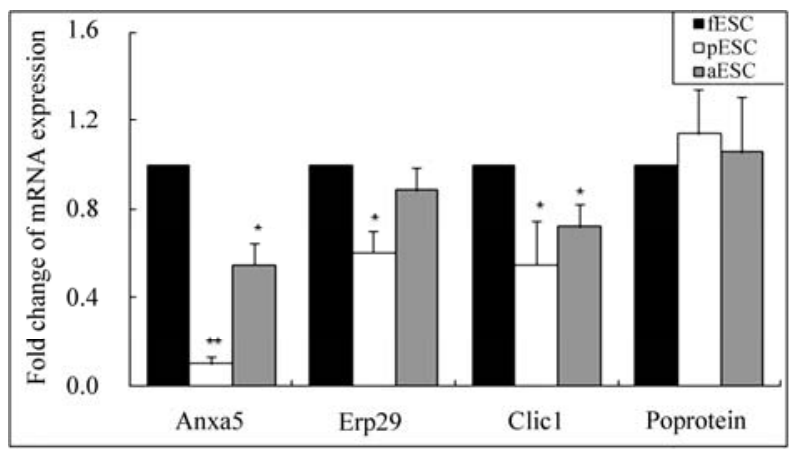

(a)

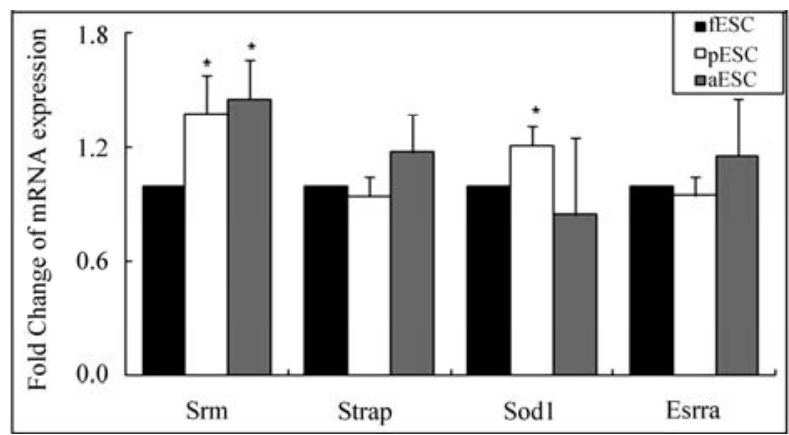

(b)

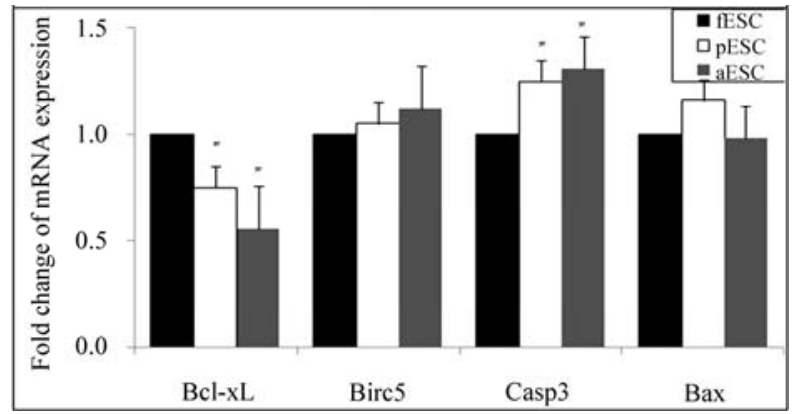

(c)

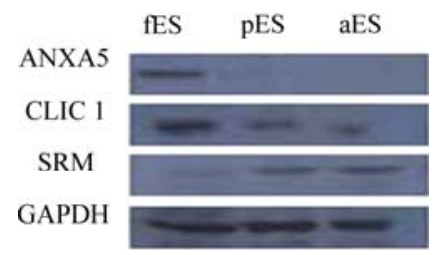

(d)

Figure 5. Relative mRNA expression levels of differentially expressed protein candidates with high (A) or low (B) expression levels in fESCs compared with both pESCs and aESCs in 2-DE analysis. Apoptosis-related genes (C) were analyzed by real time RT-PCR. Gapdh mRNA expression was used as an internal standard and its mRNA level in fESCs was designated as one-fold (baseline). Black bars, fESCs; white bars, pESCs; grey bars, aESCs. Statistically significant differences are indicated: *, $\mathbf{P}<0.05$; **, $\mathbf{P}<$ 0.01. Values are means \pm SEM for two independent cell lines. (D), Protein expression in fESCs (fES), pESCs (pES), and aESCs (aES). GAPDH protein expression was used as the control. 
negative for differentiated cell markers, Pax6 and Nes. Sex diagnosis results showed that both fESCs and aESCs contained both $\mathrm{X}$ and $\mathrm{Y}$ chromosomes.

Several transcription factors are essential for ES cell pluripotency. Octamer-binding protein 3 or 4 (Oct $3 / 4$, Oct4), a POU family member, is one such factor. Oct4 is downregulated in response to differentiation, and its upregulation induces differentiation. Therefore, a critical amount of Oct4 is required to sustain stem-cell self-renewal [17]. Also, Nanog, a homeodomain protein, was found to be capable of maintaining ES cell self-renewal, independent of the LIF/STAT3 pathway $[18,19]$. In the present study, Oct4 and Nanog were expressed in the fESCs, pESCs, and aESCs. The data partially suggested that pluripotency of pESCs and aESCs did not differ from that of fESCs. This supports evidence from a previous study [5], in which chimeras produced from pESCs generated by diploid blastocysts developed well postnatally, with no growth retardation, and the age of the chimeras did not affect the proportions of tissues contributed by pESCs. Furthermore, pESCs have the capacity to differentiate into all tissue types in the body; Surprisingly, even in organisms as complex as mice, pESCs can support full-term development, resulting in a pESC-derived newborn [5]. aESCs also exhibit a surprising ability to differentiate. Dinger et al. [20] observed widespread contributions from aESCs in fetal chimeric mice and reported that their neural differentiation potential, in terms of self-renewal properties of neural stem cells, did not differ from that of normal biparental fESCs [20]. In addition, aESCs are able to differentiate into various cell types of all three embryonic germ layers [21]. Together, homozygous ESCs, or at least pESCs, are indistinguishable from fESCs with respect to tissue/organ contribution. Reliable derivation of pluripotent pESCs or aESCs is a critical step towards the feasibility of female or male patient-specific ES cell therapy in regenerative medicine.

One of the proteins highly expressed in fESCs was identified as ANNEXIN A5 (ANXA5, spot no. 1233), a $35 \mathrm{kD}$ plasma protein. The membrane-binding capacity of ANXA5 has multiple functions, including the modulation of signalling events, a function as a Ca-channel, involvement in calcification processes, and a function as a receptor for viruses [22]. ANXA5 can also interfere with calcium and phospholipid signalling pathways [23]. Of note, ANXA5 mRNA and protein have been shown to be expressed in the zebrafish oocyte [24]. It is possible that the expression level of Anex 5 is higher in fESCs than in pESCs and aESCs, and that this may be related to fertilization and calcium oscillation upon sperm penetration into the oocyte. As seen in a previous report [25], after sperm capacitation, Anex 5 binding sites were found mainly in the post-acrosomal region of the sperm head plasma membrane. After induction of the acrosome reaction, the Anex5 binding sites were found almost only in the acrosomal region and with higher numbers of binding sites in the equatorial area.

Spot no. 2143 was also highly expressed in fESCs compared with pESCs and aESCs. This protein spot was identified as CLIC1. CLIC1, also known as NCC27, is a member of the Clic family of chloride channels, which can function as chloride channels in vitro [26,27]. These proteins have significant structural homology with glutathione-S-transferase [28]. In somatic cells, the expression of CLIC1 is localized mainly in the nuclear and vesiculo-cytoplasmic membranes. Furthermore, vesiculocytoplasmic CLIC1 colocalizes with mitochondria, and CLIC1 may play a role in the regulation of osteoblastic differentiation from mesenchymal progenitors [29]. CLIC1 protein is expressed in Xenopus oocytes in combination with the cystic fibrosis transmembrane conductance regulator (CFTR) [30]. To date, no study has reported any function associated with CLIC1 in ESCs or embryos. However, one study did report that CLIC1 might play important roles in gallbladder carcinoma metastasis, including in cell motility and invasion [31]. It would be considering that CLIC1 may be associated with lower efficiency in derivation of pESC line than fESC line [5]. During ICM outgrowth, MAPK signalling is noticeably reduced in parthenogenetic blastocysts compared with fertilized blastocysts. Though no similar study has been done for aESCs, as uniparental ESCs, aESCs may undergo intracellular processes more similar to those of pESCs than to those of fESCs. CLIC1, highly expressed in fESCs compared with pESCs and aESCs, is required further observation of its function during preimplantation embryogenesis and ESC generation in both uniparental and biparental chromosomes.

In the present study, the expression level of spermidine synthase (SRM, spot no. 2213) was higher in pESCs and aESCs than in fESCs. Spermidine synthase, an aminopropyltransferase, catalyzes the biosynthesis of polyamine spermidine from putrescine. Spermidine synthase and spermine synthase are important contributors to ion channel regulation, transcription, translation, and enzyme activities. Previously, we identified several genes that were differentially expressed in blastocyst-stage porcine parthenotes. One of these, SRM, was highly expressed only in the blastocysts of porcine parthenotes [31]. Another previous study showed upregulation of SRM mRNA following the addition of exogenous polyamines [32]. Furthermore, this upregulation was influenced by apoptosis and apoptotic-related gene expression. Higher expression of SRM in pESCs and aESCs could be related to the relatively low overall 
quality and high levels of apoptosis in pESCs and aESCs compared with fESCs. In the present study, significantly higher expression level of Casp3 and lower expression level of $B C l-x L$ in pESCs and aESCs vs. fESCs provided strong evidence in support of this idea, although no differentially expressed protein spot was identified by MS. Previous reports have indicated that polyamines were essential for normal cell growth [33] and required for apoptosis with Caspase activation [34]. Spermidine synthase gene is also essential for survival of Arabidopsis [35]. In plant cells, spermidine acts as a signalling regulator in stress signalling pathways, leading to a build-up of stress tolerance mechanisms under stress conditions [36]. Apoptosis occurs during the normal development of mammalian embryos because it helps to remove unnecessary cells, an important developmental process [37]. In pESCs and aESCs, SRM may act as a Caspase activator for cells which are needed to undergo apoptosis.

This study describes analyses of the expressed proteins in fESCs as compared with pESCs and aESCs. This information contributes to our understanding of the intracellular processes in uniparental- or biparental-derived homozygous or heterozygous ESCs, and should serve to provide insight into the functional capabilities of these distinct cell types. Although we believe that the proteins identified in this study are important for ESC therapy in the clinical setting, we should also point out that the actual function of these proteins in these types of stem cells, especially during differentiation, is at present unknown. Studying each protein individually, using gain of function, loss of function, and dominant-negative mutants, may reveal how and when these molecules contribute to the self-renewal and differentiation of ESCs.

In conclusion, two protein candidates, ANXA5 and CLIC1, were more highly expressed in fESCs compared with pESCs and aESCs. In contrast, SRM was more highly expressed in pESCs and aESCs than in fESCs. Further study of these protein candidates is needed to identify and clarify their functions, including functions related to the avoidance of immune rejection problems during ESC therapy, the maintenance of pluripotency, and the properties of ESC differentiation.

\section{ACKNOWLEDGEMENTS}

This work is supported by grant No. 20100301-061-224-001-50-00 from the Biogreen 21 program, RDA, Republic of Korea.

\section{REFERENCES}

[1] Evans, M.J. and Kaufman, M.H. (1981) Establishment in culture of pluripotential cells from mouse embryos. Nature,
292, 154-156. doi:10.1038/292154a0

[2] Thomson, J.A., Itskovitz-Eldor J., Shapiro S.S., Waknitz, M.A., Swiergiel, J.J., Marshall, V.S. and Jones, J.M. (1998) Embryonic stem cell lines derived from human blastocysts. Science, 282, 1145-1147.

doi:10.1126/science.282.5391.1145

[3] Allen, N.D., Barton, S.C., Hilton, K., Norris, M.L. and Surani, M.A. (1994) A functional analysis of imprinting in parthenogenetic embryonic stem cells. Development, 120, 1473-1482.

[4] Eckardt, S, Leu, N.A., Bradley, H.L., Kato, H., Bunting, K.D. and McLaughlin, K.J. (2007) Hematopoietic reconstitution with androgenetic and gynogenetic stem cells. Genes Deveplment, 21, 409-419. doi:10.1101/gad.1524207

[5] Li, C., Chen, Z., Liu, Z., Huang, J., Zhang, W., Zhou, L., Keefe, D.L. and Liu, L. (2009) Correlation of expression and methylation of imprinted genes with pluripotency of parthenogenetic embryonic stem cells. Human Molecular Genetics, 18, 2177- 2187. doi:10.1093/hmg/ddp150

[6] Baharvand, H., Fathi, A., Gourabi, H., Mollamohammadi, S. and Salekdeh, G.H. (2008) Identification of mouse embryonic stem cell-associated proteins. Journal of Proteome Research, 7, 412-423. doi:10.1021/pr700560t

[7] Intoh, A., Kurisaki, A., Yamanaka, Y., Hirano, H., Fukuda, H., Sugino, H. and Asashima, M. (2009) Proteomic analysis of membrane proteins expressed specifically in pluripotent murine embryonic stem cells. Proteomics, 9, 126-137. doi:10.1002/pmic.200800496

[8] Lee, C.K., Kim, H.J., Lee, Y.R., So, H.H., Park, H.J., Won, K.J., Park, T., Lee, K.Y., Lee, H.M. and Kim, B. (2007) Analysis of peroxiredoxin decreasing oxidative stress in hypertensive aortic smooth muscle. Biochimica at Biophysica Acta, 1774, 848-855.

[9] Zhang, D.X., Cui, X.S. and Kim, N.H. (2009) Involvement of polyadenylation status on maternal gene expression during in vitro maturation of porcine oocytes. Molecular Reproduction Development, 76, 881-889. doi: $10.1002 / \mathrm{mrd} .21056$

[10] Cary. Statisitics. (1985) SAS User's Gudie Version 5, NC, SAS.

[11] Torrie, RGDSa, J.H. (1980) Principles and Procedures of Statistics. New York, McGraw Hill Book Companies.

[12] Hikichi, T., Wakayama, S., Mizutani, E., Takashima, Y., Kishigami, S., Van Thuan, N., Ohta, H., Thuy Bui, H., Nishikawa, S. and Wakayama, T. (2007) Differentiation potential of parthenogenetic embryonic stem cells is improved by nuclear transfer. Stem Cells, 25, 46-53. doi:10.1634/stemcells.2006-0439

[13] Hikichi, T., Ohta, H., Wakayama, S. and Wakayama, T. (2010) Functional full-term placentas formed from parthenogenetic embryos using serial nuclear transfer. Development, 137, 2841-2847. doi:10.1242/dev.051375

[14] Wakayama, S., Ohta, H., Kishigami, S., Thuan, N.V., Hikichi, T., Mizutani, E., Miyake, M. and Wakayama, T. (2005) Establishment of male and female nuclear transfer embryonic stem cell lines from different mouse strains and tissues. Biology of Reproduction, 72, 932-936. doi:10.1095/biolreprod.104.035105

[15] Wakayama, T., Tabar, V., Rodriguez, I., Perry, A.C., Studer, L. and Mombaerts, P. (2001) Differentiation of embryonic stem cell lines generated from adult somatic cells by nuclear transfer. Science, 292, 740-743. doi:10.1126/science.1059399 
[16] Wakayama, S., Jakt, M.L., Suzuki, M., Araki, R., Hikichi, T., Kishigami, S., Ohta, H., Van Thuan, N., Mizutani, E., Sakaide, Y., Senda, S., Tanaka, S., Okada, M., Miyake, M., Abe, M., Nishikawa, S., Shiota, K. and Wakayama, T. (2006) Equivalency of nuclear transfer-derived embryonic stem cells to those derived from fertilized mouse blastocysts. Stem Cells, 24, 2023-2033.

doi:10.1634/stemcells.2005-0537

[17] Niwa, H., Miyazaki, J. and Smith, A.G. (2000) Quantitative expression of Oct-3/4 defines differentiation, dedifferentiation or self-renewal of ES cells. Nature Genetics, 24, 372-376. doi:10.1038/74199

[18] Mitsui, K., Tokuzawa, Y., Itoh, H., Segawa, K., Murakami, M., Takahashi, K., Maruyama M, Maeda M and Yamanaka S. (2003) The homeoprotein Nanog is required for maintenance of pluripotency in mouse epiblast and ES cells. Cell, 113, 631-642. doi:10.1016/S0092-8674(03)00393-3

[19] Kashyap, V., Rezende, N.C., Scotland, K.B., Shaffer, S.M., Persson, J.L., Gudas, L.J. and Mongan, N.P. (2009) Regulation of stem cell pluripotency and differentiation involves a mutual regulatory circuit of the NANOG, OCT4, and SOX2 pluripotency transcription factors with polycomb repressive complexes and stem cell microRNAs. Stem Cells Development, 18, 1093-1108. doi:10.1089/scd.2009.0113

[20] Dinger, T.C., Eckardt, S., Choi, S.W., Camarero, G., Kurosaka, S., Hornich, V., McLaughlin, K.J. and Muller, A.M. (2008) Androgenetic embryonic stem cells form neural progenitor cells in vivo and in vitro. Stem Cells, 26, 1474-1483. doi:10.1634/stemcells.2007-0877

[21] Teramura, T., Onodera, Y., Murakami, H., Ito, S., Mihara, T., Takehara, T., Kato, H., Mitani,T., Anzai, M., Matsumoto, K., Saeki, K., Fukuda, K., Sagawa, N. and Osoi, Y. (2009) Mouse androgenetic embryonic stem cells differentiated to multiple cell lineages in three embryonic germ layers in vitro. Journal of Reproduction and Development, 55, 283-292. doi:10.1262/jrd.20146

[22] Dedman BASaJR. Annexins. Biometals (1998) 11, 399-404. doi:10.1023/A:1009205925714

[23] Russo-Marie, F. and Annexin, V. (1999) Phospholipid metabolism. Clinical Chemistry and Laboratory Medicine, 37, 287-291. doi:10.1515/CCLM.1999.050

[24] Ozerova, S.G. and Minin, A.A. (2008) A study of proteins of annexin group in early fish development. IV. Identification of calcium-binding proteins in zebrafish egg by mass spectrometry. Ontogenez, 39, 222-226.

[25] Avalos-Rodriguez, A., Ortiz-Muniz, A.R., Ortega-Camarillo, C., Vergara-Onofre, M., Rosado-Garcia, A. and Rosales-Torres, A.M. (2004) Fluorometric study of rabbit sperm head membrane phospholipid asymmetry during capacitation and acrosome reaction using Annexin-V FITC. Archives of Anthology, 50, 273-285. doi:10.1080/01485010490448741

[26] Cromer, B.A., Morton, C.J., Board, P.G. and Parker, M.W. (2002) From glutathione transferase to pore in a CLIC. European Biophysics Journal, 31, 356-364. doi:10.1007/s00249-002-0219-1

[27] Ashley, R.H. (2003) Challenging accepted ion channel biology: P64 and the CLIC family of putative intracellular anion channel proteins (Review). Molecular Membrane Biology, 20, 1-11. doi:10.1080/09687680210042746

[28] Harrop, S.J., DeMaere, M.Z., Fairlie, W.D., Reztsova, T., Valenzuela, S.M., Mazzanti, M., Tonini, R., Qiu, M.R., Jankova, L., Warton, K., Bauskin, A.R., Wu, W.M., Pankhurst, S., Campbell, T.J., Breit, S.N. and Curmi, P.M. (2001) Crystal structure of a soluble form of the intracellular chloride ion channel CLIC1 (NCC27) at 1.4-A resolution. The Journal of Biological Chemistry, 276, 44993-45000. doi:10.1074/jbc.M107804200

[29] Yang, J.Y., Jung, J.Y., Cho, S.W., Choi, H.J., Kim, S.W., Kim, S.Y, Kim, H.J., Jang, C.H., Lee, M.G., Han, J. and Shin, C.S. (2009) Chloride intracellular channel 1 regulates osteoblast differentiation. Bone, 45, 1175-1185. doi:10.1016/j.bone.2009.08.012

[30] Edwards, J.C. (2006) The CLIC1 chloride channel is regulated by the cystic fibrosis transmembrane conductance regulator when expressed in Xenopus oocytes. Journal of Membrane Biology, 213, 39-46. doi:10.1007/s00232-006-0059-5

[31] Lee, H.Y., Cui, X.S., Lee, K.A. and Kim, N.H. (2006) Annealing control primer system identifies differentially expressed genes in blastocyst-stage porcine parthenotes. Zygote, 14, 71-80. doi:10.1017/S0967199406003571

[32] Cui, X.S. and Kim, N.H. (2005) Polyamines inhibit apoptosis in porcine parthenotes developing in vitro. Molecular Reproduction and Development, 70, 471-477. doi: $10.1002 / \mathrm{mrd} .20228$

[33] Pegg, A.E. (1988) Polyamine metabolism and its importance in neoplastic growth and a target for chemotherapy. Cancer Research, 48, 759-774.

[34] Stefanelli C, P.C., Tantini, B., Fattori, M., Stanic, I., Mackintosh, C.A., Flamigni, F., Guarnieri, C., Caldarera, C.M. and Pegg, A.E. (2001) Effect of polyamine depletion on caspase activation: A study with spermine synthase-deficient cells. Biochemical Journal, 355, 199-206. doi:10.1042/0264-6021:3550199

[35] Imai, A., Matsuyama, T., Hanzawa, Y., Akiyama, T., Tamaoki, M., Saji, H., Shirano, Y., Kato, T., Hayashi, H., Shibata, D., Tabata, S., Komeda, Y. and Takahashi, T. (2004) Spermidine synthase genes are essential for survival of Arabidopsis. Plant Physiology, 135, 1565-1573. doi:10.1104/pp.104.041699

[36] Kasukabe, Y., He, L., Nada, K., Misawa, S., Ihara, I. and Tachibana, S. (2004) Overexpression of spermidine synthase enhances tolerance to multiple environmental stresses and up-regulates the expression of various stress-regulated genes in transgenic Arabidopsis thaliana. Plant Cell Physiology, 45, 712-722. doi: $10.1093 / \mathrm{pcp} / \mathrm{pch} 083$

[37] Hardy, K. (1997) Cell death in the mammalian blastocyst. Molecular Human Reproduction, 3, 919-925. doi:10.1093/molehr/3.10.919 